\title{
Executivo, Legislativo e Sindicatos na Reforma Previdenciária Argentina*
}

\author{
Sidney Jard da Silva
}

\section{INTRODUÇÃO}

produção acadêmica sobre poder sindical é tributária de duas
grandes tradições: 1) o pluralismo e 2) o corporativismo. A tradi-
ção pluralista trata o poder como atributo intrínseco dos atores sociais
(coletivos ou individuais). No caso das organizações sindicais, o plura-
lismo enfatiza recursos como capacidade de mobilização, número de
afiliados, concentração espacial, patrimônio financeiro etc. Na tradi-
ção corporativista, ao contrário, o poder deixa de ser resultado de atri-
butos próprios das organizações e passa a depender das características
particulares do sistema de intermediação de interesses (Almeida,
1998). Neste caso, os estudiosos dedicam sua atenção a variáveis como
grau de centralização, monopólio de representação, modalidades de

\begin{abstract}
* Este artigo é uma versão modificada do terceiro capítulo da minha tese de doutoramento, intitulada Interação Sindicalismo-Governo nas Reformas Previdenciárias Argentina e Brasileira. Agradeço aos professores Marta Arretche, Heloísa Martins, Vera Schattan e Eduardo Noronha as críticas e sugestões à primeira versão deste artigo. Sou igualmente grato a Richard M. Locke (Massachusetts Institute of Technology - MIT) e a Juan C. Torre (Universidad Torcuato di Tella - UTDT). Minha orientadora, Maria Hermínia Tavares de Almeida, e minha colega, Simone Diniz, merecem uma menção especial pela importante contribuição que aportaram a este texto. Finalmente, quero agradecer aos pareceristas anônimos da Dados pelos valiosos comentários. À Fundação de Amparo à Pesquisa do Estado de São Paulo - Fapesp e ao Conselho Nacional de Desenvolvimento Científico e Tecnológico-CNPq, devo o suporte técnico e financeiro que viabilizaram a realização da minha pesquisa de doutorado.
\end{abstract}

DADOS - Revista de Ciências Sociais, Rio de Janeiro, Vol. 49, nº2, 2006, pp. 345 a 377. 
recrutamento etc. ${ }^{1}$ A tradição de estudos sindicais na América Latina foi fortemente influenciada por esta segunda vertente. Entretanto, a amplitude de arranjos político-institucionais que podem ser classificados como corporativistas colocou aos estudiosos do sindicalismo latino-americano a necessidade de se definir, com maior precisão, as especificidades que esses sistemas assumem em diferentes países da região, ou mesmo, em contextos históricos distintos de um mesmo país.

Ruth Collier e David Collier (1979), por exemplo, argumentam que o corporativismo não deve ser tratado como uma variável dicotômica (presente ou ausente), mas sim como uma variável contínua, em que é possível observar diferentes graus de corporativismos. No modelo analítico proposto por esses autores, é de fundamental importância distinguir se o Estado se limita a controlar e subordinar os sindicatos ou se também promove uma política de incentivo e fortalecimento da organização sindical (inducements versus constraints) ${ }^{2}$. Igualmente preocupado com a variedade de arranjos que podem ser classificados sob o genérico rótulo de corporativismo, Alfred Stepan (1980) distingue entre corporativismo inclusivo e exclusivo. No primeiro caso, mediante promoção de políticas redistributivas e de bem-estar social, o Estado incorpora os grupos de interesse ao sistema político e econômico. No segundo caso, ao contrário, por meio de medidas coercitivas, o mesmo atua no sentido de excluir os grupos de interesse. Assim como a distinção proposta por Collier e Collier (1979) sobre os mecanismos de incentivos e constrangimentos presentes nos arranjos corporativistas, a formulação de Stepan (1980:102) não é dicotômica. Segundo este autor, as políticas inclusivas e exclusivas devem ser entendidas como dois "pólos" ao redor do qual gravita a relação Estado-sociedade.

Nos últimos anos, a emergência de novas formas de relacionamento entre Estado e grupos de interesse reacendeu a preocupação dos estudiosos latino-americanos sobre os arranjos políticos corporativos ${ }^{3}$. No entanto, cumpre observar que os estudos recentes têm enfatizado muito mais a interação sindicalismo-governo do que a relação sindicato-Estado. Esta mudança de foco é importante, pois chama a atenção para o padrão negociado de implementação de mudanças, mais do que para a mera subordinação ou cooptação dos grupos de interesse pelo aparelho estatal ${ }^{4}$.

Com efeito, uma variada gama de estudos já demonstrou que, sem que houvesse mudanças significativas no sistema de intermediação de in- 
teresses, em algumas áreas setoriais das reformas, os governos foram mais suscetíveis à inclusão do sindicalismo no processo decisório do que em outras (Almeida, 1998; Cheibub e Locke, 1999; Etchemendy e Palermo, 1998). Sendo assim, considero que, para responder a questão do porquê os governos decidem negociar com as entidades sindicais, além de analisar as características particulares do sistema de intermediação de interesses, é necessário investigar o perfil dos arranjos político-institucionais que delimitam a participação sindical no processo decisório das reformas ${ }^{5}$.

Em um conhecido estudo comparativo sobre a reforma dos programas de seguro social de saúde na França, Suécia e Suíça, Ellen Immergut (1996) demonstrou que a mudança de uma determinada política exige uma sucessão de votos afirmativos em diferentes instâncias de decisão (decision points). Portanto, governos empenhados em promover reformas devem reunir votos favoráveis e reafirmar sua posição nas diferentes instâncias decisórias do processo reformista ${ }^{6}$. Nessa perspectiva, a análise dos procedimentos formais que definem as regras do jogo, bem como a composição partidária de cada uma das instâncias de decisão, é de fundamental importância para entendermos as possibilidades abertas para os grupos de interesse intervirem nos processos de mudança das políticas públicas.

Na mesma linha de argumentação, mas deslocando o foco da análise das instâncias de veto para os atores com capacidade de veto, Tsebelis (1997) fez uma importante contribuição à análise institucional ao demonstrar que a estabilidade ou mudança das políticas varia de acordo com o número de veto players, o grau de congruência entre eles (a diferença entre suas posições políticas) e sua coesão (a similaridade das posições políticas das unidades que constituem cada um deles). De acordo com esse modelo analítico, as mudanças terão menores chances de serem bem-sucedidas nos arranjos institucionais nos quais há um grande número de atores com capacidade de veto, alto grau de coesão e baixo grau de congruência. Inversamente, as mudanças terão maiores chances de serem implementadas onde há um pequeno número de veto players, com baixa coesão e alta congruência ${ }^{7}$. Neste ponto, cumpre destacar que, tanto Immergut (1996) quanto Tsebelis (1997) concentram a análise na lógica do processo decisório. Os grupos de interesse são tomados como atores externos às instâncias de decisão. Esses autores não tratam da possibilidade de os grupos de interesse contarem com representantes no interior das arenas decisórias ${ }^{8}$. 
Neste artigo, todavia, lançarei mão das noções de instância de veto e de atores com capacidade de veto para estudar a implementação de mudanças em contextos político-institucionais em que os grupos de interesse possuem representantes no interior do próprio processo decisório da reforma, mais precisamente na arena legislativa. Como veremos, faz diferença se as entidades sindicais possuem representantes localizados em instâncias decisórias do processo reformista, ou apenas exercem pressão sobre os atores com poder de veto institucional. Essas situações não são excludentes; entretanto, a primeira alternativa aumenta a probabilidade de organizações sindicais serem incluídas em um processo negociado de reforma da previdência.

\section{O PRIMEIRO PROJETO DO EXECUTIVO - JUNHO DE 1992}

Em 5 de junho de 1992, o governo Menem enviou à Honorable Cámara de Diputados de la Nación seu primeiro projeto de reforma da previdência. Tratava-se de uma reforma estrutural do sistema previdenciário argentino. A exemplo da experiência chilena, a proposta inicial era transferir do Estado para a iniciativa privada o papel de principal agente na provisão de benefícios previdenciários (Alonso, 1998; 2000; Ghilarducci e Liébana, 2000). A justificativa para a reforma era a profunda crise vivida pelo regime público de repartição, manifesta na incapacidade de autofinanciamento do regime, nos baixos benefícios pagos aos aposentados, no persistente déficit previdenciário, na iniqüidade no pagamento dos benefícios e na ineficiência estatal na administração dos recursos arrecadados (HCDN, 1993a).

O principal apelo do projeto era a possibilidade de recompor os benefícios previdenciários aos níveis estabelecidos em lei. Segundo Menem, a reforma permitiria o aumento imediato das aposentadorias: "Tão logo o Congresso sancione os projetos de reforma da previdência e de privatização da YPF [Yacimientos Petrolíferos Fiscales], todos os aponsentados passarão a receber $82 \%$ do salário da ativa. No entanto, qualquer mudança improvisada nestes projetos será objeto de veto presidencial e ficaremos sem lei, sem reforma e sem solução para os aposentados" (Ámbito Financiero, 3/6/1992:3, tradução do autor).

O governo Menem tentava impor à reforma previdenciária o estilo "decisionista" que havia sido uma das principais marcas dos seus primeiros anos de mandato (Matsushita, 1999; Palermo, 1998; Torre e Gerchunoff, 1999). No entanto, ao contrário das reformas que a antecede- 
ram, a reforma da previdência implicaria um amplo processo de negociação envolvendo o Executivo, o Legislativo e diversos grupos de interesse. O prenúncio da forte oposição que a reforma do sistema previdenciário sofreria no Congresso argentino foi sintetizado na reação indignada do deputado da Unión Cívica Radical - UCR, Raul Baglini: "em nenhuma hipótese aceitaremos a chantagem do Presidente da República, que decidiu tomar os aposentados como reféns para forçar a privatização do sistema previdenciário e o leilão da YPF". Após semanas afirmando que não é possível conceder aumento aos aposentados, o presidente volta a mentir quando diz que é necessário votar os referidos projetos para aumentar os benefícios previdenciários e instala uma falsa confrontação entre o Congresso e os aposentados (Ámbito Financiero, 4/6/1992, tradução do autor).

A iniciativa do Executivo também fue una bomba para a bancada justicialista. A complexidade técnica e alta visibilidade política da reforma colocavam os deputados peronistas em uma situação pouco confortável para aprová-la sem um debate prévio de suas conseqüências econômicas, políticas e sociais (Nino, 2003). Assim, não obstante as pressões por uma rápida aprovação, a apreciação do projeto de reforma previdenciária passou por um moroso e acirrado debate nas comissões de Previsión y Seguridad Social - PySS e Presupuesto y Hacienda - PyH. Nos quase dois anos de trâmite legislativo, a discussão parlamentar contou com a participação de entidades representativas de trabalhadores, empresários, associações de aposentados e diversos especialistas na área previdenciária (Isuani e San Martino, 1993). A resistência à introdução do sistema de capitalização partiu, sobretudo, dos deputados radicais e da bancada sindical peronista. Os opositores da reforma apresentaram quatro críticas centrais ao projeto do Executivo.

A primeira referia-se à desvinculação do sistema previdenciário do conceito de seguridade social. Os partidários dessa crítica argumentavam que o regime de capitalização se enquadrava no sistema de poupança, e não no sistema de seguridade social, o qual teria como objetivo oferecer proteção também àqueles que, durante sua vida ativa, não desenvolveram capacidade de poupança (Armendáriz, 1996). A segunda, à ausência de um estudo preliminar sobre os custos de administração do novo sistema. O projeto enviado pelo Executivo não estabelecia teto para as taxas de administração a serem cobradas pelas administradoras de fundos de pensão. Neste caso, os legisladores alertavam para o risco de "cartelização" do mercado previdenciário. A terceira re- 
feria-se à falta de mecanismos de reconhecimento das contribuições recolhidas ao regime antigo. Conforme o projeto enviado pelo Executivo, todos os menores de 45 anos seriam compulsoriamente transferidos para o regime de capitalização, mas o processo de transição de um regime para o outro não previa o reconhecimento dos aportes passados. A adoção de tal medida representaria uma perda significativa para os trabalhadores com idade próxima à linha de corte (45 anos). Finalmente, no que diz respeito à capacidade de regulamentação estatal, os opositores da reforma alegavam que não havia motivos para crer que o Estado - considerado ineficiente para administrar o sistema público - seria eficiente na supervisão do sistema privado. A essa crítica agregavam a incompatibilidade da administração privada vis-à-vis o disposto constitucional que estabelecia a organização de entidades nacionais e provinciais de seguro social "administradas pelos segurados com participação estatal" (HCDN, 2004, tradução do autor). Além das críticas, a proposta de reforma previdenciária defendida pelo Executivo suscitou a apresentação de projetos alternativos nas comissões de PySS e PyH. Os que receberam maior atenção, no debate político e acadêmico, foram os projetos apresentados pela UCR e pelo Consejo Federal de Previsión Social - Cofepres.

\section{PROJETOS ALTERNATIVOS}

O projeto alternativo apresentado pela UCR propunha uma reforma paramétrica do sistema previdenciário argentino. Entre outras coisas, previa a criação de um organismo de participação dos filiados na administração do sistema, denominado Assembléia (Asamblea), que teria a responsabilidade de analisar a situação econômica e financeira do sistema e a gestão administrativa do novo regime de repartição ${ }^{9}$. Os afiliados ao sistema também elegeriam um corpo de representantes para a Comisión Asesora de la Secretaría de Seguridad Social, encarregada de formular propostas e projetos na área de previdência social e encaminhá-las às autoridades competentes. Os integrantes da Assembléia seriam eleitos pelos Centros de Jubilados y Pensionados e se reuniriam anualmente mediante a convocação da Secretaría de Seguridad Social.

O modelo previdenciário proposto pela UCR unificaria os regimes dos trabalhadores autônomos e aqueles em relação de dependência (a adesão das províncias seria facultativa). O sistema seria financiado pela contribuição de $10 \%$ do salário dos trabalhadores em relação de dependência, $16 \%$ dos empregadores e $26 \%$ da renda dos trabalhadores autô- 
nomos. A aposentadoria por idade seria aos 65 anos para os homens e aos 60 para as mulheres, com 20 anos de contribuição. A aposentadoria por invalidez seria concedida somente aos trabalhadores que estivessem total y permanentemente impossibilitados de exercer suas atividades profissionais. Os benefícios pagos pelo sistema estariam situados entre $40 \%$ e $82 \%$ do salário recebido em atividade, a depender dos anos de contribuição dos trabalhadores. O projeto também estabelecia um teto de 10 vezes o benefício mínimo da aposentadoria ordinária. Finalmente, a reforma estabelecia um benefício básico universal por idade a todos os argentinos com mais de 70 anos e às pessoas incapacitadas com mais de 15 anos.

O projeto alternativo apresentado pelo Cofepres, órgão integrado por organismos previdenciários provinciais, também defendia a manutenção do regime público de repartição, o qual seria suplementado por um regime de capitalização voluntário. Esse projeto previa o aumento imediato da idade mínima para 65 anos, no caso dos homens, e 60 anos, para as mulheres. Também aumentava a idade de contribuição para 25 anos. O benefício previdenciário seria determinado em $2 \%$ por cada ano de contribuição, atualizados dentro dos últimos 10 anos de serviço, e seu teto seria de 3 mil pesos. Os benefícios seriam móveis, reajustados no prazo de 30 dias após o aumento dos salários dos trabalhadores ativos. $\mathrm{O}$ Estado não teria obrigação de assegurar um benefício mínimo. As aposentadorias por idade avançada deixariam de ser concedidas, e aquelas por invalidez seriam outorgadas apenas no caso de incapacidade total e permanente para o trabalho. No que se refere às pensões, o valor pago estaria condicionado ao número de dependentes: $50 \%$ do benefício, em caso de um único dependente; $67 \%$; $75 \%$; e $80 \%$ no caso de dois, três e quatro, respectivamente.

Neste primeiro momento, sem um projeto próprio, a posição da Confederación General del Trabajo - CGT-RA era muito próxima daquela defendida pela oposição ao governo justicialista, qual seja, uma reforma paramétrica do sistema previdenciário, cujas principais medidas seriam o aumento da idade da aposentadoria e do tempo de contribuição (MTSS, 1992). No início do trâmite legislativo da reforma, a bancada de deputados sindicalistas aliou-se aos deputados de oposição para obstruir a tentativa de o Executivo obter um visto bueno para o projeto enviado ao parlamento argentino. Essa dissidência do bloco sindical peronista ficou conhecida como Alianza Sindical-Radical. A possibilidade de realizar alianças ad hoc com setores de oposição dentro do Congres- 
so aumentou o poder de barganha da CGT-RA no jogo da reforma previdenciária. De um lado, os deputados sindicalistas aliaram-se à oposição para bloquear o trâmite legislativo da reforma; de outro, intensificou-se a mobilização sindical por mudanças na política econômica do governo Menem.

\section{A AMEAÇA DE GREVE DE JULHO DE 1992}

Em 1ํde julho de 1992, um mês após o envio do projeto de reforma previdenciária ao Congresso, o Comité Central Confederal da CGT-RA anunciou o primeiro chamado de paro general no governo Menem. A ameaça de greve marcava o início de um período de crescentes dificuldades para manter o apoio sindical à política de reformas estruturais implementada no País. O indicativo de greve, anunciado em 28 de julho, coincidia com o prazo que o Executivo havia dado ao Legislativo para aprovar a reforma da previdência. Não por acaso, a rejeição à reforma tornou-se uma das principais bandeiras da paralisação. No mesmo período, a CGT-RA orientou o bloco sindical na Câmara dos Deputados a postergar o tratamento da reforma previdenciária até que os sindicatos apresentassem um projeto alternativo (Ámbito Financiero, 2/7/1992:17). A reforma da previdência também se tornou um dos elementos centrais nas negociações para suspender o chamado de greve geral. Em meados de julho, o jornal Ámbito Financiero anunciava que o governo Menem havia rejeitado a proposta da CGT-RA de suspender a greve em troca do arquivamento do projeto de reforma do sistema previdenciário argentino.

Diante dos boatos de que o governo estaria negociando um novo "pacto negro" com o sindicalismo, Menem veio a público anunciar que o decreto da produtividade, a desregulamentação do sistema de obras sociales e a privatização do sistema previdenciário não seriam negocia$\operatorname{dos}^{10}$. Ademais, orientou seu gabinete a deixar claro, para toda a sociedade, que "A reivindicação da CGT-RA é para a cúpula sindical, não para os trabalhadores" (Clarín, 17/7/1992:3, tradução do autor). Ainda que na mídia Menem radicalizasse seu discurso em relação aos seus velhos aliados do movimento sindical, nos bastidores representantes do governo e da CGT-RA trabalhavam para encontrar uma solução para a crise instaurada.

Menem designou seus principais ministros para negociar com a direção da CGT-RA, entre eles Domingo Cavallo (Economia), Rodolfo Díaz 
(Trabalho) e Julio César Aráos (Saúde e Ação Social). Entre as concessões a serem oferecidas estavam a criação de uma comissão para estudar as mudanças no sistema de obras sociales, a emissão de um bônus estatal para liquidar as dívidas desse sistema e a convocação do Consejo del Salario, la Productividad y el Empleo. Em troca, o governo exigia a assinatura de uma cláusula de paz social, na qual a CGT-RA se comprometia a apoiar o projeto de reforma da previdência e não exercer medidas de fuerza em um período de três anos.

A direção da Central considerou a proposta inaceptable. Segundo os dirigentes da CGT-RA, a cláusula de paz social seria uma carta blanca para o governo. Em 16 de julho de 1992, a direção cegetista comunicou ao então ministro do Trabalho, Rodolfo Díaz, que nos próximos dias seria definida a data da greve geral (Clarín, 17/7/1992:3). A ameaça da CGT-RA surtiu efeito. Avaliando o impacto negativo da greve sobre o programa de estabilização econômica que começava a dar seus primeiros sinais positivos, o governo Menem abriu uma nova rodada de negociações com a Central. O próprio ministro da Economia, Domingo Cavallo, principal artífice do Plan de Convertibilidad, foi designado para oferecer um novo pacote de concessões aos dirigentes sindicais.

O acordo representou um recuo importante em relação à postura intransigente assumida pelo governo Menem no início do conflito. Pontos até então considerados fora da pauta de negociação foram incluídos no protocolo assinado pelos dirigentes da CGT-RA e o ministro da Economia. Entre as principais concessões figuravam a revisão do decreto que vinculava os aumentos salariais à produtividade, o repasse direto dos recursos das obras sociales para os sindicatos, a emissão de títulos públicos para pagamento da dívida do sistema de obras sociales, o fim da transferência compulsória dos menores de 45 anos para o regime de capitalização e um aumento emergencial para as aposentados.

A seguir os principais pontos da ata assinada por representantes da CGT-RA e do governo:

1. Negociação Coletiva - compromisso de buscar a sanção do projeto de lei de negociação coletiva, contemplando os interesses e os princípios dos atores sociais. Com a sanção da lei, será permitida a negociação coletiva entre as partes e serão ampliados os critérios para negociação salarial dentro do marco da estabilidade, eqüidade e justiça social. Da mesma forma, serão contemplados mecanismos de participação e con- 
sulta à Confederación General del Trabajo para a regulamentação da referida lei;

2. Sistema de Arrecadação - a arrecadação será feita mediante o sistema de boleto bancário, em uma única operação de pagamento. O boleto da Administración Nacional de la Seguridad Social - Anses e o de cada obra social serão separados, o da Anses será acompanhado de um talão de informações. O boleto das obras sociales será confeccionado de forma que permita o processamento de dados magnéticos. Os depósitos serão diretos nas contas das obras sociales, sem conta intermediária. A fiscalização e execução dos aportes e das contribuições estarão a cargo das obras sociales;

3. Obras Sociales - compromisso de estabelecer mecanismos de participação e consulta para reformar o sistema de obras sociales. A reforma deve contemplar a reestruturação do sistema, a garantia das prestações, o equilíbrio financeiro, a eficiência administrativa e o princípio de solidariedade;

4. Passivo das Obras Sociales e Planos de Vivienda - conforme a Lei no 24.070, se estabelece o compromisso de regulamentar o passivo das Obras Sociales e Planos de Vivienda dentro do prazo de 30 dias, estando o cumprimento da lei a cargo dos ministérios de Salud y Acción Social, Trabajo y Seguridad Social e Economía, com intervenção do Tribunal de Cuentas;

5. Sistema Previdenciário - reconhecer a necessidade de reformar a legislação vigente a fim de garantir os direitos dos trabalhadores ativos, dos aposentados e dos pensionistas. Com o intuito de melhorar o projeto do Executivo, buscar-se-á garantir os direitos básicos dos trabalhadores de todas as idades, evitando cortes discriminatórios. Reajuste emergencial para aposentados e pensionistas, implementando mecanismos que permitam ampliar a arrecadação do sistema;

6. Consejo Nacional del Empleo, la Productividad y el Salario Mínimo y Móvil - iniciará suas atividades de forma imediata, de acordo com as propostas dos atores sociais, ratificadas pelo Decreto no 1.148 /92 do presidente da República. Este ato referenda o compromisso de diálogo e participação a fim de melhorar a situação econômica e social, implementando mecanismos que permitam encontrar soluções e garantir a paz social (Página 12, 18/7/1992:3; Ámbito Financiero, 20/7/1992:12). 
No que tange à reforma da previdência, o acordo abria o caminho para o desmembramento do projeto original em duas partes distintas: a primeira trataria da recomposição dos benefícios aos patamares previstos em lei; a segunda incumbia-se da reforma propriamente dita. Cumpre observar que esta era a proposta defendida pela bancada de deputados sindicalistas no interior do Legislativo. Em agosto de 1992, Menem enviou um novo projeto de reforma da previdência ao Congresso. Entre as principais mudanças estavam o fim do limite de idade para adesão ao novo sistema e o reconhecimento das contribuições ao antigo regime de repartição. Contudo, mesmo considerando um avanço em relação ao projeto anterior, a bancada de deputados sindicalistas decidiu não apoiar a nova proposta enviada pelo Executivo. No mesmo período, Menem decidiu abrir um canal exclusivo de interlocução com representantes de empresários e trabalhadores. Em 15 de setembro de 1992, por meio do decreto presidencial no 1.717/92, foi criado o Consejo Nacional Económico para la Producción, la Inversión y el Crecimiento - CNEPIyC. Este órgão se converteria no principal instrumento utilizado pelo governo para lograr o apoio da direção da CGT-RA à reforma da previdência (entrevista concedida ao autor pelo vice-presidente da Comisión de Previsión y Seguridad Social, Juan Manuel Moure, $13 / 8 / 2003)$.

\section{REFORMA PREVIDENCIÁRIA E CONCERTAÇÃO SOCIAL}

A criação de um órgão especial de consulta e assessoramento - reunindo representantes dos empresários, governo e trabalhadores no âmbito do Ministerio de Economía y Obras y Servicios Sociales - MEOSS foi anunciada como um novo período no processo de implementação das reformas estruturais na Argentina. Em uma publicação interna, justificando a criação do CNEPIyC, a equipe técnica do Ministerio de Economía classificava a experiência argentina de participação social na formulação de políticas públicas em três tipos diferenciados de órgãos de consulta: 1) Tecnocráticos - limitados a elaborar planos e programas que se esgotam no teórico ou são apenas parcialmente adotados pelos políticos no poder; 2) Participacionistas - caracterizados por seu compromisso prévio com um determinado governo ou plano econômico, ao qual aportam idéias ou correções, mas sem exigências substanciais; 3 ) Concertacionistas - aqueles em que os atores sociais (sindicatos e grupos empresariais) avançam sobre a decisão política e se convertem em virtuais parceiros do Estado (MEOSSP, 1992). 
De acordo com essa classificação, o governo Menem estaria passando de uma situação na qual predominavam os conselhos do tipo tecnocráticos e participacionistas para um período quando predominariam os conselhos concertacionistas, os quais se destacavam pelo maior espaço para os grupos de interesse influenciarem nas decisões políticas. Um aspecto de fundamental importância na criação do CNEPIyC foi a abertura de um canal de negociação no interior do próprio Ministerio de Economía, uma antiga reivindicação do sindicalismo argentino, haja vista que este ministério centralizava as principais decisões do governo ${ }^{11}$. Trinta e duas entidades representativas dos trabalhadores e empresários foram convidadas a compor o CNEPIyC. No caso da CGT-RA, foram designados cinco titulares: Aníbal Martinez (construção civil), José Pedraza (ferroviários), José Rodríguez (mecânicos), Oscar Baldassini (correios) e Oscar Lescano (eletricitários).

A abertura oficial do CNEPIyC ocorreu em 15 de outubro de 1992 nas dependências do Ministerio de Economía. Nesta ocasião, a pauta restringiu-se à estrutura, regimento e funcionamento do Conselho. Entre as entidades convidadas, apenas a Federación Agraria Argentina FAA não enviou representante. A CGT-RA foi representada por três dos seus cinco secretários-gerais: José Pedraza, Oscar Baldassini e Oscar Lescano. Na primeira reunião ordinária, realizada em 22 de outubro de 1992, os integrantes do CNEPIyC acordaram os requisitos básicos que deveriam orientar o estabelecimento de um novo marco regulatório de Promoción Industrial. Na reunião seguinte, que se deu em 29 de outubro de 1992, entraram para a agenda do Conselho a reorganização do comércio exterior, o acordo fiscal com as províncias e a desregulamentação dos serviços profissionais (Acta del CNEPIyC, 29/10/1992). Nessas duas primeiras reuniões, o CNEPIyC havia sido bem-sucedido na formulação de políticas consensuais entre seus membros. Entretanto, um novo impasse na interação sindicalismo-governo ofuscaria a busca de soluções concertadas no âmbito do Conselho. Em novembro de 1992, a CGT-RA realizaria a sua primeira greve geral contra a política econômica menemista, a qual exigia, entre outras coisas, o cumprimento do acordo firmado com a Central em julho do mesmo ano.

\section{A GREVE GERAL DE NOVEMBRO DE 1992}

A greve geral realizada em 9 de novembro de 1992 deve ser analisada dentro do contexto das divisões internas do sindicalismo argentino. 
Desde a vitória peronista nas eleições de 1989, o movimento sindical esteve dividido entre sindicalistas "leais" e aqueles que assumiram uma postura crítica em relação ao novo modelo socioeconômico (McGuire, 1997; Murillo, 1997; 2001). Do lado menemista situava-se o grupo dos Quince e dos Veinticinco, liderados por Guerino Andreoni (comerciários), Raúl Amin (mecânicos) e Luis Barrionuevo (gastronômicos); de outro, os sindicalistas alinhados a Lorenzo Miguel (metalúrgicos), Saúl Ubaldini (cervejeiros) e Juan Palácios (transportes). Desta divisão, emergiram duas centrais: a CGT-San Martín, liderada por Guerino Andreoni; e a CGT-Azopardo, conduzida por Saúl Ubaldini. Menem contou com o apoio da CGT-San Martín para implementar parte importante de sua agenda política: privatizações, regulamentação do direito de greve, demissão de servidores públicos, suspensão dos convênios coletivos no setor público etc. Por outro lado, as principais mobilizações contra a política econômica menemista foram realizadas pelos sindicatos organizados na CGT-Azopardo.

Após mais de dois anos de ruptura, os sindicalistas da CGT-San Martín e da CGT-Azopardo decidiram iniciar um processo de reunificação da Central. A principal justificativa para a unificação era a necessidade de enfrentar de forma unitária os desafios colocados pela reforma trabalhista, previdenciária e do sistema de obras sociales. No processo de reunificação, os cargos de direção da CGT-RA foram subdivididos para comportar as diferentes orientações políticas: cinco secretários-gerais, cinco secretários-adjuntos, cinco secretários-financeiros etc. A direção cegetista seria ocupada, a cada ano, por um dos seus cinco secretários-gerais (entrevista concedida ao autor pelo assessor sindical da CGT-RA, Mario Gasparri, 11/9/2003). O primeiro ano de gestão foi entregue ao "independente" Oscar Lescano (Luz y Fuerza). Na composição da primeira diretoria colegiada da CGT-RA, houve um claro predomínio dos sindicalistas moderados: Oscar Lescano (eletricitários), José Rodríguez (mecânicos), Alberto Martinez (metalúrgicos). O bloco menemista estava representado por José Pedraza (ferroviários) e os combativos por Juan Manuel Palácios (transportes).

As divergências em relação à política econômica implementada no país e o sistemático não-cumprimento dos acordos firmados entre a direção moderada da CGT-RA e o governo Menem fortaleceram a posição dos setores mais combativos da Central, os quais ameaçaram com uma nova ruptura, caso os sindicalistas moderados não adotassem uma medida de fuerza. Neste contexto de crescentes desavenças entre os 
grupos que compunham a direção da CGT-RA, o chamado de greve geral de novembro de 1992 foi uma clara concessão do grupo moderado ao grupo dos combativos, com o objetivo de evitar uma nova ruptura da CGT-RA. O movimento foi bem-sucedido no setor industrial, base tradicional do sindicalismo cegetista. A Dirección Nacional de Relaciones Laborales, subordinada ao Ministerio de Trabajo, registrou que $100 \%$ dos trabalhadores da Autolatina acataram o chamado de greve, 90\% dos trabalhadores em concessionárias, indústria têxtil, naval e de vidro; 70\% dos trabalhadores da Mercedez Benz, 60\% da construção, $43 \%$ dos plásticos e $30 \%$ dos trabalhadores em confecção e vestuário. A Unión Industrial Argentina estimou a participação dos trabalhadores industriais em 70\% (Noticias Gremiales, 18/11/1992:2).

Nos demais setores, a avaliação do sucesso do movimento variou muito. Enquanto a direção colegiada da CGT-RA avaliava que, em média, 90\% dos trabalhadores haviam acatado o chamado de paro general, o governo e os meios de comunicação avaliavam que, no máximo, $40 \%$ dos trabalhadores haviam participado da paralisação ${ }^{12}$. Para além do debate quantitativo sobre a porcentagem de trabalhadores que aderiram à paralisação, cumpre observar que a CGT-RA não logrou nenhuma concessão por parte do governo Menem em conseqüência da greve geral. Não por acaso, a novidade do cenário pós-greve ficou por conta de uma nova cisão no interior do sindicalismo argentino, que deu origem à Central de los Trabajadores Argentinos - $\mathrm{CTA}^{13}$.

\section{A PROPOSTA ALTERNATIVA DA CGT-RA}

Poucos dias após a nova cisão da CGT-RA, a direção cegetista apresentou ao governo Menem sua proposta de reforma da previdência, a qual representava uma importante mudança na posição da Central em relação à reforma do sistema previdenciário. A principal novidade era a reivindicação de as entidades sem fins lucrativos (cooperativas, fundos mútuos, entidades sindicais) organizarem seus próprios fundos de pensão.

A seguir os principais pontos da proposta elaborada pela direção da CGT-RA:

1. Manter a estrutura do regime público e limitar o regime de capitalização a um sistema de caráter suplementar e voluntário, descartando o caráter obrigatório deste último; 
2. Ampliar as entidades capazes de administrar os fundos de previdência. Além dos bancos, poderão cumprir a função de Administradoras de Fondos de Jubilación y Pensión - AFJP, os sindicatos, os fundos mútuos, as cooperativas e as sociedades anônimas;

3. Diferenciar os aportes que serão destinados ao regime público, que serão depositados em nome do Sistema Único de la Seguridad Social SUSS, dos aportes voluntários para regime de capitalização, os quais serão depositados diretamente na conta individual de cada empregado;

4. O trabalhador que optar por contribuir para o regime de capitalização individual deverá ter a liberdade de escolher a modalidade de capitalização, não podendo haver um único modo de capitalizar;

5. A única modalidade de recebimento do benefício será a renda vitalícia assegurada, ficando expressamente proibida a renda programada;

6. Para melhorar o valor do benefício previdenciário, será incorporado à lei um artigo com a finalidade de incentivar os empregadores a desenvolverem programas contributivos a favor dos empregados. Estes incentivos serão integralmente dedutíveis do imposto de renda;

7. Todos os agentes que integram o sistema de capitalização, e que não são definidos como AFJP, serão controlados pelos organismos legais que atualmente já exercem essa função (Clarín, 12 /11 /1992: 23; Noticias Gremiales, 18/11/1992:10).

A proposta apresentada pela CGT-RA antecipava duas das principais modificações a serem incluídas no projeto original do governo: a possibilidade de outras entidades, inclusive sindicatos, constituírem AFJP(s); e o caráter opcional do regime de capitalização, isto é, a possibilidade de o trabalhador escolher entre continuar no regime de repartição ou migrar para o regime de capitalização. Uma semana após a apresentação do projeto cegetista, governo e sindicalistas anunciavam a assinatura de um novo acordo a respeito da reforma da previdência, $\mathrm{o}$ qual incluía, no projeto original do Executivo, algumas das demandas apresentadas pela direção da CGT-RA. Entre elas a possibilidade das entidades sindicais conformarem seus próprios fundos de pensão.

A seguir os 11 pontos da ata resultante da negociação estabelecida no âmbito CNEPIyC: 
1. Permitir que, além das sociedades anônimas, outras instituições de diferente natureza jurídica, tais como entidades sem fins lucrativos (sindicatos, fundações, fundos mútuos, cooperativas, associações civis etc.), possam criar Administradoras de Fondos de Jubilación y Pensión - AFJP. Todas as AFJP, qualquer que seja sua constituição jurídica, ficarão sujeitas à totalidade das normas estabelecidas pelo Sistema Integrado de Jubilaciones y Pensiones - SIJP e pelo seu único órgão de controle (Superintendencia de AFJP);

2. Com o objetivo de garantir a livre escolha da(s) AFJP(s) por parte dos contribuintes, se estabelece que deve ficar terminantemente proibido subordinar a concessão de benefícios, qualquer que seja sua índole, à afiliação e transferência do trabalhador a uma determinada AFJP;

3. Garantir a participação dos empregados, dos empregadores e dos beneficiários do sistema previdenciário por intermédio de um organismo que assegure o cumprimento dos objetivos de fiscalização e regulação do SIPJ;

4. Assegurar que as rendas vitalícias das administradoras se ajustem, em matéria de esperança de vida, às regras ditadas em conjunto pela Superintendencia de Seguro de la Nación e pela Superintendencia de las Administradoras de Fondos de Jubilación y Pensión;

5. Aprofundar as definições relacionadas à cobertura de aposentadoria por invalidez;

6. Explicitar no texto legal os requisitos e procedimentos necessários para a abertura ou o fechamento das administradoras;

7. As contribuições que correspondam à(s) AFJP(s) serão creditadas automaticamente, uma vez recebidos os depósitos pela entidade bancária;

8. Definir de maneira precisa o conceito de remuneração, de tal forma que fiquem fora dele os denominados benefícios sociais;

9. Evitar a dupla tributação ocasionada pelo tratamento fiscal conjunto das comissões das AFJP(s) e do primeiro pagamento das companhias de seguro (morte ou invalidez). Assegurar, além disso, o tratamento fiscal homogêneo para todas as $\operatorname{AFJP}(s)$;

10. Detalhar no texto da lei as sanções a que estão sujeitos os diferentes atores, tais como empregados, empregadores, funcionários do setor 
público e privado (administradoras e companhias de seguros), por não cumprirem as novas normas legais;

11. Dar conhecimento ao Honorable Congreso de la Nación e aos distintos blocos parlamentares sobre os aspectos consensuados na presente ata (Ámbito Financiero, 27/11/1992:27; Clarín, 27/11/1992:18).

A ata do acordo continha dois pontos de fundamental importância para o apoio da CGT-RA à reforma da previdência: 1) a permissão para entidades sem fins lucrativos constituir administradoras de fundos de pensão; e 2) a criação de um organismo de supervisão do sistema previdenciário, composto por representantes de empresários, governo e trabalhadores. No entanto, o a poio formal da CGT-RA ao projeto de reforma previdenciária ainda não significava o aval para a bancada sindical votar à favor do projeto do Executivo nas comissões de PySS e PyH do Congresso. A Central condicionaria o voto favorável dos deputados sindicalistas à aprovação de uma nova Ley de Convenios Colectivos:

“O Consejo de la Producción, la Inversión y el Crecimiento, composto por representantes do governo, da CGT e dos empresários, logrou, finalmente, chegar a um consenso sobre o projeto de reforma previdenciária, cuja sanção parlamentar ocorrerá até o final do ano, desde que se obtenha previamente uma rápida aprovação da Ley de Convenios Colectivos. Em todo caso, os representantes sindicais no Consejo anteciparam que os deputados sindicalistas não votarão a favor da reforma do sistema previdenciário até que nova norma sobre paritarias tenha força de lei" (Noticias Gremiales, 3/12/1992:10, tradução do autor).

A condicionalidade para o apoio da CGT-RA ao projeto de reforma previdenciária, assinalava que, a partir de então, o ator central no debate da reforma passaria a ser o bloco de parlamentares sindicalistas na Câmara dos Deputados. Assim, longe de representar o fim de um longo debate, o apoio da Central à reforma previdenciária apenas constituía uma nova fase no processo de negociação entre sindicalismo e governo.

\section{A BANCADA SINDICAL}

Um passo importante na análise das reformas previdenciárias é identificar quais são os atores com efetivo poder de veto institucional. O movimento sindical, como outros movimentos sociais, pode pressionar aqueles que decidem a sorte das reformas, mas não possui poder institucional para vetá-las (Immergut, 1996; Tsebelis, 1997; 1998). No entan- 
to, legisladores vinculados ao movimento sindical podem defender os interesses de seus representados no interior do Parlamento e, neste caso, a bancada de deputados sindicalistas pode constituir um ator político com capacidade de bloquear (total ou parcialmente) os projetos em trâmite legislativo.

A reforma previdenciária foi encaminhada à Honorable Cámara de Diputados de la Nación sob o formato de projeto de lei do Poder Ejecutivo. De acordo com o regimento interno da Câmara, a proposta foi encaminhada para as comissões de PySS e PyH. Segundo esse mesmo regimento, o projeto não poderia ser apreciado pelo Plenário sem antes receber um parecer favorável da maioria absoluta dos membros das duas comissões em reunião conjunta ${ }^{14}$. No final de seus trabalhos, as comissões legislativas encarregadas de analisar o projeto de reforma previdenciária deveriam apresentar um parecer favorável (dictamen de mayoría) com a assinatura de todos os deputados que se manifestaram a favor do substitutivo a ser encaminhado ao Plenário da Câmara dos Deputados.

No interior da comissão de PySS, os deputados justicialistas detinham 12 dos 25 cargos (48,0\%); portanto, necessitavam de mais um voto para alcançar a maioria absoluta. Essa situação se repetia na comissão de $\mathrm{PyH}$, em que o Partido Justicialista - PJ contava com 17 deputados dos 34 titulares $(50,0 \%)$. O segundo partido com maior número de titulares, a UCR, contava com nove votos (36,0\%) na comissão de PySS e 13 votos $(38,2 \%)$ na comissão de $\mathrm{PyH}$. Os demais partidos contavam com quatro titulares $(16,0 \%)$ na comissão de PySS e quatro titulares $(11,7 \%)$ na comissão de PyH. Ou seja, em sessão conjunta das duas comissões, os peronistas detinham 29 titulares $(49,1 \%)$, e os não-peronistas, 30 titulares $(50,8 \%)$.

Tabela 1

Comisión de Previsión y Seguridad Social

\begin{tabular}{l|c|c|c|c}
\hline \multirow{2}{*}{ Bloco/Partido } & \multicolumn{2}{|c|}{ Titulares } & \multicolumn{2}{c}{ Sindicalistas } \\
\cline { 2 - 5 } & $\mathbf{N}$ & $\mathbf{\%}$ & $\mathbf{N}$ & $\mathbf{\%}$ \\
\hline PJ & 12 & 48,0 & 5 & 41,6 \\
UCR & 9 & 36,0 & 0 & 0,0 \\
MP & 1 & 4,0 & 0 & 0,0 \\
UCEDE & 1 & 4,0 & 0 & 0,0 \\
PBJ & 1 & 4,0 & 0 & 0,0 \\
PF & 1 & 4,0 & 0 & 0,0 \\
\hline Total & $\mathbf{2 5}$ & $\mathbf{1 0 0 , 0}$ & $\mathbf{5}$ & $\mathbf{2 0 , 0}$ \\
\hline
\end{tabular}

Fonte: Boletín Informativo, 22/12/1992. 
Executivo, Legislativo e Sindicatos na Reforma Previdenciária Argentina

Tabela 2

Comisión de Presupuesto y Hacienda

\begin{tabular}{l|c|c|c|c}
\hline \multirow{2}{*}{ Bloco/Partido } & \multicolumn{2}{|c|}{ Titulares } & \multicolumn{2}{c}{ Sindicalistas } \\
\cline { 2 - 5 } & $\mathbf{N}$ & $\mathbf{\%}$ & $\mathbf{N}$ & $\mathbf{\%}$ \\
\hline PJ & 17 & 50,0 & 2 & 11,7 \\
UCR & 13 & 38,2 & 0 & 0,0 \\
DP & 1 & 2,9 & 0 & 0,0 \\
Bloq. & 1 & 2,9 & 0 & 0,0 \\
UCEDE & 1 & 2,9 & 0 & 0,0 \\
US & 1 & 2,9 & 0 & 0,0 \\
\hline Total & $\mathbf{3 4}$ & $\mathbf{1 0 0 , 0}$ & $\mathbf{2}$ & $\mathbf{5 , 9}$ \\
\hline
\end{tabular}

Fonte: Boletín Informativo, 22/12/1992.

Não obstante possuir um peso reduzido no Congresso, no interior das comissões de PySS e $\mathrm{PyH}$, em que o projeto deveria receber um parecer favorável antes de ser enviado para o Plenário da Câmara, a bancada sindical contava com uma posição privilegiada para bloquear o trâmite legislativo da reforma da previdência. Na comissão de PySS, o bloco sindical perfazia $20,0 \%$ de seus titulares e $41,6 \%$ da bancada peronista. $\mathrm{Na}$ comissão de $\mathrm{PyH}$, os deputados sindicalistas perfaziam 5,9\% dos titulares e $11,7 \%$ dos representantes do PJ. Considerando que o Executivo necessitava da votação coesa de sua bancada (e mais um voto) para lograr um parecer favorável em reunião conjunta destas comissões, a bancada sindical estava na situação de "fiel da balança"15. Valendo-se de sua localização estratégica, os deputados sindicalistas bloquearam várias tentativas de o Executivo aprovar o projeto de reforma previdenciária no interior das comissões de PySS e PyH. Como veremos, além das concessões referentes à própria reforma previdenciária, a bancada sindical também utilizou seu poder de veto para forçar o governo Menem a abrir negociações em outras áreas de interesse do sindicalismo argentino.

\section{UM "ACUERDO GLOBAL"}

O ano de 1993 foi particularmente importante na relação dos deputados sindicalistas com o Executivo. Após quase quatro anos de uma tensa relação entre a bancada sindical e o governo peronista, a renovação de parte do Legislativo e o projeto de reforma constitucional (incluindo a reeleição para presidente da República) constituíam um incentivo para governo e sindicalistas iniciarem um novo período de aproxima- 
ção. Entre os anos de 1991 a 1993, havia 18 deputados sindicalistas na Câmara de Deputados, sendo que 13 finalizariam o mandato em dezembro de 1993. Portanto, a proximidade das eleições representava um forte incentivo para a CGT-RA buscar uma maior aproximação com o governo e ampliar sua participação na lista peronista ${ }^{16}$. Por outro lado, nesse mesmo ano, iniciavam-se as articulações para a reforma constitucional, na qual um dos principais pontos seria a possibilidade de reeleição para a presidência da República. Portanto, era igualmente importante para o governo Menem garantir a coesão de sua base parlamentar a favor da reforma constitucional.

Em 7 de janeiro de 1993, Menem anunciou o lançamento do Plan Social. As medidas anunciadas neste plano contemplavam, entre outras coisas, a implementação de programas de emprego para jovens, subsídios para os aposentados, reestruturação do sistema hospitalar, incentivo à microempresa e desregulamentação parcial do sistema de obras sociales. A oposição denunciou o lançamento do plano como mais uma manobra eleitoral do governo. Entretanto, o Plan Social também era uma resposta aos apelos de setores da base governista, entre os quais se destacam os dirigentes sindicais, que exigiam políticas compensatórias para as camadas sociais atingidas de forma negativa pelo plano de estabilização econômica e pelas políticas de reformas estruturais. Inicialmente, a reação da direção cegetista ao Plan Social foi ambígua. Um grupo de sindicalistas liderados pelos dirigentes estatais Andrés Rodríguez (Unión del Personal Civil de la Nación - UPCN) e José Luis Lingeri (Federación Nacional de Trabajadores de Obras Sanitarias - FENTOS), em reunião com o Gabinete Social da Presidência, declarou apoio ao programa. No entanto, esse apoio foi rejeitado em uma reunião do Consejo Directivo da CGT-RA, e os sindicalistas que aderiram ao plano, sem consulta prévia à Central, foram invitados a rever suas posições (Noticias Gremiales, 13/1/1993:3).

No centro da polêmica estava a desregulamentação do sistema de obras sociales. O sindicalismo argentino opunha-se à desregulamentação total desse sistema. Entretanto, a desregulamentação parcial proposta pelo governo, ou seja, a possibilidade de os sindicatos competirem entre si, opunha os interesses dos maiores sindicatos ao dos menores. Diante da divisão dos sindicatos em relação à desregulamentação parcial, o Consejo Directivo da CGT-RA decidiu apoiar as medidas sociais anunciadas pelo governo e rechaçar a desregulamentação do sistema de obras sociales. A esse respeito, Oscar Lescano, co-secretário-geral da 
CGT-RA declarou que: "A CGT aceita a complementação entre as obras sociales por intermédio da implementação de um sistema de contra-prestações, mas nunca a concorrência entre elas" e acrescentou que "de nenhuma forma aceitaremos a aplicação deste decreto" (Noticias Gremiales, 13/1/1993:3, tradução do autor).

A oposição pontual da CGT-RA ao Plan Social era o sinal de que se abria mais um espaço de negociação entre sindicatos e governo. Iniciava-se a construção de um acuerdo global que envolveria, entre outros temas, a desregulamentação parcial do sistema de obras sociales, a flexibilização dos critérios de produtividade, a reforma do sistema previdenciário e a reforma política. Após várias reuniões com representantes do governo, a adesão da CGT-RA ao Plan Social foi anunciada no final de janeiro de 1993. Na mesma ocasião, Gerardo Martínez, dirigente da Unión Obrera de la Construcción de la República Argentina - UOCRA, foi designado supervisor do programa de eliminação das escuelas rancho e José Luis Lingeri (Fentos), foi designado para integrar a comissão encarregada pelo plan de saneamiento de aguas (Noticias Gremiales, 27/1/1993:3).

O novo acordo foi comemorado pelas principais lideranças da CGT-RA. Em reunião com os membros do Gabinete Social da Presidência, José Pedraza, co-secretário-geral cegetista, enfatizou que a participação dos sindicatos no Plan Social iria "muito além das formalidades", acrescentando que "quem deve decidir se um presidente deve seguir no seu cargo é o povo e não alguns dirigentes" (Noticias Gremiales, 27/1/1993:3, tradução do autor). A última fase do acordo dar-se-ia em torno da negociação de um novo decreto que desvincularia, parcialmente, os reajustes salariais dos índices de produtividade. Em reunião com o então ministro do Trabalho, Henrique Rodríguez, os dirigentes da Central comprometeram-se em orientar o voto favorável da bancada sindical na reforma da previdência, mediante o compromisso do governo em editar um novo decreto que substituiria o Decreto no 1.334/91 (produtividade).

Na edição de 19 de fevereiro de 1993, o jornal Ámbito Financiero anunciava a realização de mais um pacto negro entre o governo Menem e a CGT-RA: "Agora se trata da nova política de negociação do salário. Põe-se seriamente em risco o princípio da produtividade de Domingo Cavallo como limite para os aumentos salariais. Em troca, o governo obtém no Congresso o apoio dos sindicalistas para lograr a aprovação 
da demorada reforma previdenciária" (Ámbito Financiero, 19/2/1993:1, tradução do autor). Em 24 de fevereiro de 1993, em uma tumultuada sessão conjunta das comissões de PySS e PyH, o governo Menem, finalmente, logrou o dictamen de mayoría necessário para enviar o projeto de reforma da previdência para o Plenário da Câmara dos Deputados. A bancada justicialista apresentou um parecer favorável com exatamente 29 assinaturas. Entre as 29 firmas que endossavam o parecer, seis pertenciam ao bloco sindical. Entre os deputados sindicalistas, apenas Luis Guerrero da Unión Obrera Metalúrgica - UOM não assinou o dictamen de mayoría apresentado pela bancada justicialista.

Um mês depois de aprovado o parecer favorável ao projeto de reforma da previdência nas comissões de PySS e PyH, o diário oficial argentino (Boletín Oficial) trazia dois decretos de interesse para o sindicalismo: o Decreto no 447 /93, de 17 de março de 1993, e o Decreto no 470/93, de 18 de março de 1993. O primeiro regulamentava a Ley no 24.185 (convenios colectivos para trabajadores del estado). Esta lei, sancionada em 16 de dezembro de 1992, havia sido proposta pelo deputado sindicalista German Abdala (PJ) e definia critérios para a negociação coletiva no setor público (Orlansky, 2000). O segundo abria espaço para a desvinculação dos ajustes salariais em relação aos critérios de produtividade. O novo regime de negociação coletiva seria misto: a vinculação dos aumentos salariais ao incremento da produtividade continuaria válida para os convênios por ramo de atividade; mas, no âmbito das empresas, prevaleceria a "livre negociação" entre sindicatos e empresários.

Mais uma vez, a reação da CGT-RA ao decreto expedido pelo governo foi ambígua. De um lado, o grupo de sindicalistas menemistas, liderados por Andrés Rodríguez (UPCN), manifestou seu apoio ao decreto: "Estamos de acordo em tudo, não há críticas a serem formuladas" (Página 12, 2/4/1993, tradução do autor). Por outro lado, o grupo de sindicalistas moderados e combativos rejeitou a proposta de descentralização das negociações coletivas. Oscar Lescano, um dos principais articuladores do acordo, declarou que teria sido enganado pelo ministro do Trabalho Enrique Rodríguez. Segundo ele, a primeira versão do Decreto no 470/93 não previa a descentralização da negociação coletiva: "Estou realmente decepcionado. Este homem [Enrique Rodríguez] nos enganou. Foram acrescentadas três linhas que não contaram com o apoio sindical. Este não é o texto acordado" (Página 12, 2/4/1993, tradução do autor). O fato é que, não obstante os desentendimentos sobre o conteúdo do decreto, o acordo entre a CGT-RA e o governo Menem 
destravou o trâmite da reforma previdenciária nas comissões legislativas e, ao mesmo tempo, estabeleceu um novo marco para o regime salarial argentino, tanto no que se refere à descentralização das negociações coletivas quanto à revogação da produtividade como único critério de aumento salarial.

\section{NEGOCIAÇÃO EM MÚLTIPLAS ARENAS}

A passagem do projeto do Executivo para o Plenário da Câmara dos Deputados coincidiu com uma importante mudança na direção da CGT-RA. No começo de abril de 1993, o metalúrgico Naldo Brunelli, dirigente da UOM, assumiu o comando da Secretaria Geral da Central. É digno de nota que a mudança na direção da CGT-RA ocorreu justamente quando os sindicalistas "moderados" tiveram suas principais reivindicações atendidas: abertura dos fundos de pensão às organizações sindicais, inclusão do sindicalismo no Plan Social, desregulamentação parcial do sistema de obras sociales, regulamentação do convênio coletivo no setor público e desvinculação das negociações salariais aos índices de produtividade. A partir desse momento, a direção da CGT-RA foi entregue ao grupo de sindicalistas que se opunha ao caráter compulsório da previdência privada, um dos principais pontos ainda pendentes no debate legislativo da reforma previdenciária. Naldo Brunelli era da direção de um dos sindicatos industriais mais críticos à política econômica menemista. Atingida negativamente pelo processo de privatizações e reestruturação produtiva, a UOM realizou mais greves durante o governo Menem do que durante o governo Raúl Alfonsín.

No interior do Legislativo, os deputados da UOM eram os que mais resistiam à proposta de reforma previdenciária enviada pelo Executivo. Os dirigentes da UOM também apoiaram o abaixo-assinado nacional organizado pela Mesa Coordinadora de los Jubilados - MCJ e pela CTA, o qual reuniu um milhão de assinaturas reivindicando a realização de um plebiscito nacional a respeito da reforma previdenciária. No ato de entrega do abaixo-assinado, no qual também estiveram presentes os sindicalistas Lorenzo Miguel e Saúl Ubaldini, o metalúrgico Naldo Brunelli declarou que: "Não se pode falar em apoio da CGT ao projeto de reforma previdenciária, nem ao trabalho dos deputados sindicalistas, porque na reunião do Consejo Directivo não houve votação e nada foi decidido" (El Cronista, 11/3/1993:4, tradução do autor). 
Em 14 de abril de 1993, após quatro tentativas malogradas, o governo Menem conseguiu reunir o quórum necessário (130 deputados) para iniciar a apreciação da reforma previdenciária no Plenário. O bloco sindical dividiu-se, mas a maioria dos dirigentes seguiu a orientação do grupo moderado. Entre os sindicalistas que continuaram a estratégia de boicotar o quórum para a apreciação da matéria, três eram da UOM: Luis Guerrero, Horacio Salusso e Roberto Monteverde ${ }^{17}$. O quórum para discussão colocava o projeto de reforma previdenciária em um momento crucial. A cada instância que avançava, desde as comissões até a discussão em Plenário, o bloco sindical tinha reduzido seu poder de veto. Neste momento, a intensificação das negociações entre representantes da CGT-RA e do governo tornou-se um elemento central no apoio à atuação da bancada sindicalista no Congresso.

Na última semana de maio de 1993, governo e sindicalistas voltaram a ser reunir - na pauta um novo acordo sobre a descentralização das negociações coletivas e a proposta de adiamento da desregulamentação parcial do sistema de obras sociales. No encontro, o ministro do Trabalho também apresentou um novo anteprojeto da reforma trabalhista a ser discutido com os representantes de empresários e trabalhadores ${ }^{18}$. No âmbito da reforma da previdência, a nova direção da CGT-RA obteve uma concessão de fundamental importância: os trabalhadores poderiam escolher entre permanecer no regime de repartição ou migrar para o regime de capitalização. Com essas propostas, Menem conseguiu retomar o apoio da CGT-RA ao projeto de reforma da previdência. No dia 29 de abril de 1993, após quase um ano de negociações, a bancada sindicalista juntou-se ao bloco peronista para votar a favor da reforma previdenciária. Conforme registra o jornal Ámbito Financiero (30/4/1993:2, tradução do autor): "Em nenhum momento anterior, o bloco do PJ havia reunido 112 deputados das suas próprias fileiras".

Após a aprovação da reforma na Câmara dos Deputados, o Consejo Directivo da Central recomendou a aprovação, sem mudanças, do projeto enviado ao Senado. A seguir um trecho do documento no qual a CGT-RA faz um balanço do longo processo de negociação da reforma previdenciária:

“a) Conseguimos converter o sistema em triplemente opcional: os trabalhadores poderão permanecer no Estado, aportar ao Banco Nación (com garantia) ou escolher um operador privado.

b) Reduzimos o custo do sistema privado, o Estado assumirá parte da cobertura por falecimento e por invalidez dos trabalhadores que já es- 
tavam no sistema. Assim, o setor privado só assumirá o risco que lhe cabe.

c) Atendendo as prementes necessidades sociais insatisfeitas, conseguimos direcionar os investimentos dos fundos do sistema privado para a construção de moradias, estradas, e outras obras públicas, haja vista que, além do benefício social que implicam, geram reativação econômica e crescimento do emprego.

d) Garantimos o apoio às economias regionais por intermédio dos investimentos facultados às $\mathrm{AFJP}(\mathrm{s})$.

e) Logramos que as entidades sem fins lucrativos possam formar administradoras e entrar ou sair livremente do sistema de capitalização.

f) O Estado Nacional, de acordo com as disposições constitucionais aplicáveis, garantirá aos atuais aposentados os direitos adquiridos pelas leis vigentes antes da promulgação da nova legislação".

No final do mesmo documento, a Central recomendava à Honorable Cámara dos Senadores da República Argentina:

"Por tudo isso e diante do significado transcendental que a reforma previdenciária assim conformada adquire para a totalidade dos trabalhadores, solicitamos respeitosamente à Cámara de Senadores o tratamento e aprovação do projeto aprovado pela Cámara de Diputados, incluindo as iniciativas propostas pela CGT-RA; e ao PEN solicitamos sua conseqüente promulgação. Tudo isso sem introduzir mudanças que alterem ou desvirtuem o espírito da lei e os direitos que reconhece aos trabalhadores" (Noticias Gremiales, 13/5/1993:11, tradução e ênfases do autor).

Em setembro de 1993, seguindo a orientação do Executivo, o Senado argentino sancionou, sem modificações, o projeto de reforma da previdência. No segundo semestre de 1994, dois anos após o envio do projeto de reforma previdenciária ao Congresso, entraria em operação o SIJP.

\section{CONSIDERAÇÕES FINAIS}

A CGT-RA utilizou recursos tradicionais do sindicalismo para introduzir suas demandas no processo de reforma da previdência: greves, manifestações públicas, lobbies, negociações tripartites etc. Entretanto, o principal instrumento utilizado pela Central para forçar o governo Menem a atender suas reivindicações foi a localização estratégica da bancada sindical no processo decisório da reforma. As principais con- 
cessões obtidas pelo sindicalismo argentino foram alcançadas no período em que o projeto de reforma da previdência estava sob apreciação das comissões de PySS e PyH, instâncias de veto nas quais o governo Menem dependia do apoio dos deputados sindicalistas para avançar no trâmite legislativo da reforma. A reforma previdenciária assumiu papel central em um complexo processo de negociação envolvendo temas tão distintos quanto a desregulamentação parcial do sistema de obras sociales, compensação para os custos sociais das reformas implementadas no país (Plan Social), desvinculação dos aumentos salariais aos índices de produtividade e a definição de um novo marco regulatório para a negociação coletiva no setor público e privado.

Em linhas gerais, podemos dividir as concessões obtidas pelo sindicalismo argentino no processo de reforma previdenciária em dois grandes grupos: 1) concessões endógenas (intra-sistema previdenciário); e 2) concessões exógenas (extra-sistema previdenciário). As primeiras foram aquelas relacionadas ao próprio conteúdo da reforma: fim do limite de idade (45 anos), reconhecimento das contribuições ao sistema anterior, supervisão tripartite, opção entre o regime de repartição e capitalização, participação sindical nos fundos de pensão etc. As segundas foram aquelas relacionadas a outras áreas de interesse do sindicalismo, como a regulamentação da negociação coletiva no setor público, a alteração do decreto que condicionava os aumentos salariais aos índices de produtividade e a desregulamentação parcial do sistema de obras sociales. Em ambos os casos, a localização estratégica da bancada de deputados sindicalistas no trâmite legislativo da reforma previdenciária foi de fundamental importância para aumentar o poder de barganha da CGT-RA e forçar o governo Menem a negociar com o sindicalismo.

(Recebido para publicação em junho de 2005)

(Versão definitiva em abril de 2006) 


\section{Executivo, Legislativo e Sindicatos na Reforma Previdenciária Argentina}

\section{NOTAS}

1. A clássica distinção entre pluralismo e corporativismo, elaborada por Philippe Schmitter (1974), influenciou toda uma geração de pesquisas sobre o sindicalismo latino-americano. As principais características do pluralismo, segundo esse autor, são: número ilimitado de organizações competitivas, não-ordenadas hierarquicamente, autodeterminadas, não especificamente autorizadas, reconhecidas, subsidiadas, controladas ou criadas pelo Estado e que não exercem monopólio de representação de suas categorias. Em contraposição, o corporativismo distingue-se pelo número limitado de organizações compulsórias, não-competitivas, hierarquicamente organizadas, funcionalmente diferenciadas, autorizadas, reconhecidas, subsidiadas, controladas ou criadas pelo Estado e que exercem monopólio de representação de suas categorias.

2. Cumpre observar que a distinção entre os mecanismos de subordinação e cooptação presentes nos arranjos corporativos assumiu particular importância nos estudos sobre o desenvolvimento dos sistemas previdenciários latino-americanos. Destacam-se, neste caso, os diversos trabalhos que buscam elucidar o papel do Estado e dos grupos de interesse na definição do caráter estratificado da previdência social na América Latina (Mesa-Lago, 1977; Cohn, 1980; Malloy, 1986).

3. A produção acadêmica brasileira é farta de exemplos neste sentido. Ver, entre outros, os trabalhos de Almeida (1995; 1996); Arbix (1996); Martins Rodrigues (1990) e Noronha (1999).

4. Ver, por exemplo, os trabalhos de Acuña e Smith (1996); Almeida e Moya (1997); Etchemendy e Palermo (1998) e Murillo (2001).

5. No caso brasileiro, a importância dos arranjos políticos institucionais na mudança das políticas públicas tem sido ressaltada, entre outros autores, por Almeida (1998), Arretche (1996), Coelho (1998), Figueiredo e Limongi (1998) e Melo (1997).

6. Conforme Immergut (1996:146): “as posições de veto não são entidades físicas, mas pontos de incerteza estratégica, decorrentes da própria lógica do processo decisório. Até mesmo uma pequena mudança nas normas constitucionais ou nos resultados eleitorais pode provocar mudanças na localização das posições de veto e em sua importância estratégica. Assim, as normas constitucionais formais e os resultados eleitorais determinam o contexto em que se dá a formulação das políticas. É aí que se abre o espaço para a influência dos grupos de interesse".

7. Nas palavras do próprio Tsebelis (1997:107): “Em linhas bem gerais, e seguindo meu argumento, os sistemas que têm múltiplos veto players incongruentes e coesos deverão revelar níveis mais elevados de estabilidade no processo de formulação de políticas do que os sistemas que contam apenas com um único veto player ou com um pequeno número de veto players sem coesão e congruentes".

8. Para ser mais preciso, Tsebelis (1997:99) considera essa possibilidade apenas nos arranjos do tipo neocorporativo: "Por exemplo, nos países corporativistas, as decisões sobre salários (que acarretam conseqüências econômicas mais gerais) são tomadas pelo governo, mas com a aprovação de dois veto players adicionais: os representantes dos trabalhadores e das empresas".

9. Entre as principais medidas propostas, o projeto previa a criação da Administración Nacional de la Seguridad Social, que seria responsável pela gestão do Régimen Naci- 
onal de Jubilaciones y Pensiones, o Régimen Nacional de Protección Social, o Régimen Nacional del Voluntariado de la Seguridad Social, o Régimen Nacional de Subsidios Familiares e o Régimen Nacional de Subsidios por Desempleo, os quais seriam financiados e administrados de forma independente (Armendáriz, 1996).

10. O serviço de saúde argentino é composto por três sistemas: 1) o público; 2) o pré-pago; e 3) as obras sociales. Este último é mantido com contribuição obrigatória de trabalhadores e empresários e administrado pelas organizações sindicais com personería gremial. Ao lado das mensalidades sindicais (entre 1\% e 3\% do salário), as contribuições para as obras sociales ( $8 \%$ dos empregadores e $6 \%$ dos empregados) representam um dos principais pilares da sustentação financeira dos sindicatos argentinos. Há relativo consenso entre os estudiosos de que a disputa pelo controle das obras sociales constituiu uma das principais fontes de conflito entre Menem e a CGT-RA no processo de reformas estruturais (Cortés e Marshall, 1999; Etchmendy e Palermo, 1998; Lodola, 1995).

11. Cumpre registrar que o secretário de Seguridad Social, formalmente subordinado ao Ministerio de Trabajo, havia sido indicado pelo ministro de Economía (entrevista concedida ao autor pelo então secretário de Seguridad Social do governo Menem, Walter Schulthess, 4/9/2003). Sobre a importância dos atores estatais (presidente, coalizão governista, burocracia ministerial) na definição do escopo das reformas previdenciárias, ver Coelho (2003).

12. Em entrevista concedida ao autor em $28 / 7 / 2003$, Rodolfo Daer, secretário-geral da CGT-RA, atribuiu as dificuldades para expandir o movimento grevista ao apoio da sociedade argentina ao processo de privatização promovido pelo governo Menem.

13. Devido às restrições da legislação sindical, primeiro a CTA foi constituída como uma "alternativa sindical", em 14 de novembro de 1992, para só mais tarde ser reconhecida como uma "central sindical", oficialmente registrada pelo Ministerio de Trabajo em 27 de maio de 1997. Conforme registra Castro (2001:69): "Esta central foi reconhecida oficialmente pelo Ministério do Trabalho como 'sindicato simplesmente inscrito' em 1997, um fato inédito na história sindical argentina e que ocorreu devido às pressões provenientes do sindicalismo internacional e da OIT, já que a Argentina ratifica a Convenção 87 sobre Liberdade e Autonomia Sindicais. A demora no reconhecimento foi de ordem política, devido às pressões da CGT-RA, tendo o governo usado como justificativa para sucessivas negativas o estatuto da CTA que contradizia a lei de associações profissionais".

14. Para uma proposição ser apreciada pelo Plenário da Câmara, sem passar pela comissão pertinente, é necessário o apoio de $2 / 3$ dos parlamentares em sessão de "informe" com a presença de representantes do Poder Executivo (HCDN, 1993).

15. A localização estratégica no interior das comissões legislativas oferecia aos deputados sindicalistas um poder maior do que a sua efetiva representação na Câmara dos Deputados e na bancada do PJ (Etchmendy e Palermo 1998; Torre, 1999; Torre e Gerchunoff, 1999). Entre 1983 e 1993, a bancada sindical havia apresentado uma tendência decrescente no interior do Legislativo argentino. Em 1983, os deputados sindicalistas representavam 13,8\% da Câmara e 31,5\% da bancada peronista; em 1993, representavam 3,9\% da Câmara e 7,8\% do bloco justicialista.

16. O sistema eleitoral argentino é de representação proporcional de lista fechada, ou seja, o eleitor vota no partido. Para uma discussão mais aprofundada do sistema po- 


\section{Executivo, Legislativo e Sindicatos na Reforma Previdenciária Argentina}

lítico e partidário argentino, ver Mustapic (2000). Para uma introdução geral sobre sistemas eleitorais, ver Nicolau (2002).

17. Os outros dois eram Dante Camaño (gastrônomicos) e José Rodríguez (mecânicos).

18. Inicialmente, a CGT-RA rejeitou o novo anteprojeto de reforma trabalhista apresentado pelo governo Menem. O resultado do novo processo de negociação só seria concretizado em 25 de julho de 1994 com a subscrição - por representantes dos empresários, governo e trabalhadores - do Acuerdo Marco para el Empleo, la Productividad y Equidad Social (MTSS, 1994).

\section{REFERÊNCIAS BIBLIOGRÁFICAS}

ACUÑA, Carlos H. e SMITH, William C. (1996), “La Economía Política del Ajuste Estructural: La Lógica de Apoyo y Oposición a las Reformas Neoliberales". Desarrollo Económico, vol. 36, no 141, pp. 355-389.

ALMEIDA, Maria H. T. de. (1995), “Além do Corporativismo: Interesses Organizados e Democratização", in L. Sola e L. M. Paulani (orgs.), Lições da Década de 80. São Paulo, Edusp/Unrisd.

(1996), Crise Econômica e Interesses Organizados. São Paulo, Edusp.

(1998), "Sindicatos em Tempos de Reforma". São Paulo em Perspectiva, vol. 12, no 1, pp. 3-9.

e MOYA, Maurício. (1997), “A Reforma Negociada: O Congresso e a Política de Privatização". Revista Brasileira de Ciências Sociais, vol. 12, no 34, pp. 119-132.

ALONSO, Guillermo V. (1998), “Democracia y Reformas: Las Tensiones entre Decretismo y Deliberación. El Caso de la Reforma Previsional Argentina". Desarrollo Económico, vol. 38, no 150, pp. 595-626.

. (2000), Política y Seguridad Social en la Argentina de los 90. Buenos Aires, FLACSO.

ARBIX, Glauco A. (1996), Uma Aposta no Futuro: Os Primeiros Anos da Câmara Setorial da Indústria Automobilística. São Paulo, Scritta.

ARRETCHE, Marta T. S. (1996), “Mitos da Descentralização: Mais Democracia e Eficiência nas Políticas Públicas?". Revista Brasileira de Ciências Sociais, vol. 31, no 11, pp. 44-66.

ARMENDÁRIZ, Alejandro. (1996), Labor Parlamentaria. Buenos Aires, HCD, Tomo II.

CASTRO, Maria S. P. de. (2001), As Mudanças nas Leis Trabalhistas e no Perfil Sindical no Brasil e na Argentina na Década de 90. Dissertação de Mestrado, Programa de Pós-Graduação em Integração da América Latina - Prolam.

CHEIBUB, Z. B. e LOCKE, R. M. (1999), “Reforma Administrativa e Relações Trabalhistas no Setor Público". Cadernos ENAP, no 18, pp. 7-70. 


\section{Sidney Jard da Silva}

COELHO, Vera S. P. (1998), "Interesses e Instituições na Política de Saúde". Revista Brasileira de Ciências Sociais, vol. 13, no 37, pp. 115-128.

. (2003), "Poder Executivo e Reforma da Previdência na América Latina”, in V. S. P. Coelho (org.), A Reforma da Previdência Social na América Latina. São Paulo, Fundação Getúlio Vargas Editora.

COHN, Amélia. (1980), Previdência Social e Processo Político no Brasil. São Paulo, Editora Moderna.

COLLIER, Ruth B. e COLLIER David. (1979), “Inducements versus Constraints: Disaggregating 'Corporatism'”. The American Political Science Review, vol. 73, no 4, pp. 967-986.

CORTÉS, Rosalía e MARSHALL, Adriana. (1999), “Estrategia Económica, Instituciones y Negociación Política en la Reforma Social de los 90". Desarrollo Económico, vol. 39, no 154, pp. 195-212.

ETCHEMENDY, Sebastián e PALERMO, Vicente. (1998), “Conflicto y Concertación: Gobierno, Congreso y Organizaciones de Interés en la Reforma Laboral de Primer Gobierno de Menem (1989-1995)". Desarrollo Económico, vol. 37, no 148, pp. 559-590.

FIGUEIREDO, Argelina C. e LIMONGI, Fernando. (1998), "Reforma da Previdência e Instituições Políticas". Novos Estudos CEBRAP, vol. 51, pp. 63-90.

GHILARDUCCI, Teresa e LIÉBANA, Patricia L. (2000), “Union's Role in Argentine and Chilean Pension Reform". World Development, vol. 28, no 4, pp. 743-764.

HONORABLE CÁMARA DE DIPUTADOS DE LA NACIÓN - HCDN. (1992), Breve Comentario del Reglamento de la Cámara de Diputados de la Nación. Buenos Aires, HCDN.

(1993a), “Mensaje del Poder Ejecutivo". Buenos Aires, HCDN, pp. 6.870-6.876.

. (2004), Constitución de la Nación. Buenos Aires, HCDN (http:/ / www.diputados. gov.ar/).

IMMERGUT, Ellen M. (1996), “As Regras do Jogo: A Lógica da Política de Saúde na França, na Suíça e na Suécia". Revista Brasileira de Ciências Sociais, vol. 30, no 11, pp. 139-165.

ISUANI, Ernesto A. e SAN MARTINO, Jorge A. (1993), La Reforma Previsional Argentina: Opciones y Riesgos. Buenos Aires, Miño y Dávila Editores S.R.L.

LODOLA, Germán J. (1995), “La Modalidad de la Relación Estado-Sindicatos en la Recta Final del Menemismo: Juegos en dos Arenas", in R. Sidicaro e J. Mayer (orgs.), Política y Sociedad en los Años del Menemismo. Buenos Aires, Universidad de Buenos Aires.

MALLOY, James M. (1986), A Política da Previdência Social no Brasil. Rio de Janeiro, Graal (tradução de Maria José Lindgren Alves).

MARTINS RODRIGUES, Lêoncio. (1990), Partidos e Sindicatos: Escritos de Sociologia Política. São Paulo, Ática.

MATSUSHITA, Hiroshi. (1999), “Un Análisis de las Reformas Obreras en la Primera Presidencia de Menem: La Perspectiva de Opción Estratégica", in S. S. Gonzáles e F. Bosoer (orgs.), El Sindicalismo en Tiempos de Menem. Buenos Aires, Ediciones Corregidor. 


\section{Executivo, Legislativo e Sindicatos na Reforma Previdenciária Argentina}

MCGUIRE, James. (1997), Peronism without Perón: Unions, Parties, and Democracy in Argentina. Stanford, Stanford University Press.

MELO, Marcus André B. C. de. (1997), “As Reformas Constitucionais e a Previdência Social", in E. Diniz eS. Azevedo (orgs.), Reforma do Estado e Democracia no Brasil: Dilemas e Perspectivas. Brasília, UnB/ENAP.

MESA-LAGO, Carmelo. (1977), Modelos de Seguridad Social en América Latina: Estudio Comparativo. Buenos Aires, Ediciones Siap-Planteos (tradução de Mario R. dos Santos).

MINISTERIO DE ECONOMÍA Y OBRAS SOCIALES Y SERVICIOS PÚBLICOS MEOSSP. (1992), Consejo Nacional Económico para la Producción, la Inversión y el Crecimiento: Antecedentes y Bibliografía. Buenos Aires, MEOSSP.

MINISTERIO DE TRABAJO Y SEGURIDAD SOCIAL - MTSS. (1992), Análisis de las Opiniones y Posicionamentos de Diferentes Actores Sociales acerca de la Reforma del Sistema Previsional Argentino. Buenos Aires, MTSS.

(1994), Acuerdo Marco para el Empleo la Productividad y la Equidad Social. Buenos Aires, MTSS.

MURILLO, Maria V. (1997), “La Adaptación del Sindicalismo Argentino a las Reformas de Mercado en la Primera Presidencia de Menem". Desarrollo Económico, vol. 37, no 147, pp. 419-446.

. (2001), Labor Unions, Partisan Coalitions, and Market Reforms in Latin America. Cambridge, Cambridge University Press.

MUSTAPIC, Ana M. (2000), “Oficialistas y Diputados: Las Relaciones Ejecutivo-Legislativo en la Argentina". Desarrollo Económico, vol. 39, no 156, pp. 571-595.

NICOLAU, Jairo M. (2002), Sistemas Eleitorais. Rio de Janeiro, Fundação Getulio Vargas Editora.

NINO, Mariano. (2003), “Reforma Previsional: La Subordinación del Interés Público en el Proceso Democrático de Decisión y Negociación en la Argentina. Revista Realidad Económica, no 195 (http:/ / www.iade.org.ar).

NORONHA, Eduardo G. (1999), Entre a Lei e a Arbitrariedade: Mercados e Relações de Trabatho no Brasil. São Paulo, LTr.

ORLANSKY, Dora. (2000), Reforma del Estado y Empleo Público: Innovaciones en las Condiciones Laborales (Argentina 1989-1999). Trabalho apresentado no III Congreso Latinoamericano de Sociología del Trabajo. Buenos Aires, Argentina, 17-20 de maio.

PALERMO, Vicente. (1998), “Os Caminhos da Reforma na Argentina e no Brasil”. Lua Nova, no 45, pp. 131-162.

SCHMITTER, Philippe C. (1974), "Still the Century of Corporatism?". The Review of Politics, vol. 36, no 1, pp. 85-131.

STEPAN, Alfred. (1980), Estado, Corporativismo e Autoritarismo. Rio de Janeiro, Paz e Terra (tradução de Marina Leão Teixeira Viriato de Medeiros).

TORRE, Juan C. (1999), “El Sindicalismo a la Defensiva”. Todo es Historia, no 389, pp. 54-62. 
e GERCHUNOFF, Pablo. (1999), “La Economía Política de las Reformas Institucionales en Argentina: Los Casos de la Política de Privatización de Entel, la Reforma de la Seguridad Social y la Reforma Laboral". Working Paper R-349, New York, Banco Interamericano de Desarrollo.

TSEBELIS, George. (1997), “Processo Decisório em Sistemas Políticos: Veto Players no Presidencialismo, Parlamentarismo, Multicameralismo e Pluralismo". Revista Brasileira de Ciências Sociais, vol. 12, no 34, pp. 89-117.

. (1998) [1990], Jogos Ocultos: Escolha Racional no Campo da Política Comparada. São Paulo, Edusp.

\title{
ABSTRACT \\ The Executive and Legislative Branches and Trade Unions in the Argentine Social Security Reform
}

This article analyzes the interaction between organized labor and government during reform of the pension system in Argentina. The purpose is to investigate the political and institutional conditions favorable to the inclusion of trade unions in a negotiated pension reform process. The Argentine pattern of union-government interaction was shown to be shaped more by the peculiarities of the decision-making process than by the demands and power of union organizations.

Key words: unionism; pension reform; Executive-Legislative relations

\author{
RÉSUMÉ \\ Exécutif, Législatif et Syndicats dans la Réforme du Système de Retraite \\ Argentin
}

Dans cet article, on analyse le processus d'interaction syndicates-gouvernement dans la réforme du système de retraite argentin. On cherche à savoir dans quelles conditions politico-institutionnelles les syndicats ont plus de chances d'être inclus dans un processus négocié de réforme du système de retraite. On voit que le modèle d'interaction syndicates-gouvernement dans cette réforme a plutôt suivi les carac- 
Executivo, Legislativo e Sindicatos na Reforma Previdenciária Argentina

tères intrinsèques du processus décisionnel du pays que les revendications et sources de pouvoir des organisations syndicales.

Mots-clé: syndicalisme; réforme du système de retraite; relations pouvoir exécutif-pouvoir législatif 